\title{
MLANA Gene
}

National Cancer Institute

\section{Source}

National Cancer Institute. MLANA Gene. NCI Thesaurus. Code C28629.

This gene plays a role in the development and maturation of melanosomes. 